\title{
Three manuscript copies of the Collection of Proverbs by al-Maydāni from the Institute of Oriental Manuscripts of the Russian Academy of Sciences, the Oriental Department of Gorky Library, St. Petersburg State University, and the National Library of Berlin
}

\author{
Y. Y. J.Hana, A. A. Mokrushina, \\ E. K. Akhmatshina \\ St. Petersburg State University, \\ 7-9, Universitetskaya nab., St. Petersburg, 199034, Russian Federation
}

For citation: Hana Y.Y.J., Mokrushina A.A., Akhmatshina E.K. Three manuscript copies of the Collection of Proverbs by al-Maydāni from the Institute of Oriental Manuscripts of the Russian Academy of Sciences, the Oriental Department of Gorky Library, St. Petersburg State University, and the National Library of Berlin. Vestnik of Saint Petersburg University. Asian and African Studies, 2018, vol. 10, issue 2, pp. 210-229. https://doi.org/10.21638/11701/spbu13.2018.206

This paper presents an analysis of three manuscript copies of the Collection of Proverbs by the famous Muslim scholar-linguist al-Maydānī. Two of the copies are part of St Petersburg manuscript collections: the collection of the Institute of Oriental Manuscripts of the Russian Academy of Sciences and the collection of the Oriental Department of Gorky Library at St. Petersburg State University. The third copy is part of the holdings of the National Library of Berlin. The al-Maydānī Collection of Proverbs is a collection of Arabic proverbs arranged in an alphabetical order. Each proverb is accompanied by a commentary on individual words, grammatical constructions, and the origins and uses of the proverbs. The collection is prefaced by the author and includes twenty-eight chapters, one for each letter of the Arabic alphabet. Two additional chapters contain the list of Arab battle dates, the sayings of Muhammad and some prominent figures of Islam. Interest in the work al-Maydāni is still alive today; his work Mağma 'al-'amtāl continues to be reprinted. Most proverbs, which the author included in his work several centuries ago, are widely used to this day. The study of the surviving copies of this manuscript makes it possible to get the most complete impression of one of the largest and most important works of the Arab thinker and scholar al-Maydānī, and also enables researchers to look at the whole cultural and historical layer through the prism of proverbs used in living speech.

Keywords: codicology, Arabic manuscript, manuscript copies, Arabic, proverbs, folklore.

To date, more and more relevant are studies related to the study of various manuscripts that were created in the eastern languages. Knowledge and experience accumulated over the centuries were reflected in the pages of numerous treatises on philosophy, history, philology, medicine and other fields of knowledge.

As the number of manuscripts grew they formed private and public collections. The largest of which are based in Damascus, Baghdad, Medina, Basra, Merv, Nishapur, Bukha-

(C) Санкт-Петербургский государственный университет, 2018 
ra, Jerusalem, Cairo, Kairouan, Cordoba, Istanbul and a number of other cities. With the manuscripts so widely distributed there is a need for their systematization $[1, p .4]$.

While originally the area of distribution of manuscripts was mainly limited to Muslim countries the situation drastically changed in the $16^{\text {th }}$ and $17^{\text {th }}$ centuries when Europeans grew interested in Oriental languages and cultures as a whole and Arab manuscripts, in particular. Gradually, collections of Arabic manuscripts began to take shape in European libraries and private collections initially in Spain, Italy, the Netherlands, France and Sweden, and later in other countries. During the same period, the first attempts were made by European Arabic scholars to systematize the accumulated library collections of Arabic manuscripts. V. Postel, J. Golius, S. de Sasi and I. Reiske laid the foundation for the further development and cataloging of the Arabic manuscript heritage. Nevertheless, these were only the first attempts to systematize the knowledge of Arabic manuscripts. Studies involving a comprehensive analysis of medieval Arabic writings did not come out until the $19^{\text {th }}$ century. The same period saw the creation of the first academic catalogs of the largest collections of Arabic manuscripts held at various libraries including at the National Library in Paris, libraries in London, Berlin, Madrid, Vienna, Munich, Leiden, St. Petersburg, Oxford, and Copenhagen.

At the end of $19^{\text {th }}$ century, K. Brokelman makes an attempt to make an overview of all the accumulated material about Arabic writings, mainly relying on printed catalogs. The first edition of his two-volume work, The History of Arabic Literature [2; 3], was published in 1898 and became a reference point for further work in this field. Brokelman's work was continued by the Turkish researcher of the Arabic manuscript heritage, literature and art F. Sezgin, who wrote the thirteen-volume History of the Arab Heritage [4], which is considered to be the most complete work on the history of Arabic science and literature.

In Russia, A. B. Khalidov and I. B. Mikhailova compiled a comprehensive bibliographic reference book of Arabic manuscripts published in 1982 [1], the first and still unique Russian undertaking in creating a consolidated bibliography of Arabic manuscript catalogs.

In the 20th century, interest in manuscript collections persisted and the first detailed descriptions of valuable manuscripts came out that did not only contain studied texts but a detailed textual analysis of them. Despite the emergence of new works on the description and systematization of manuscripts, much of the Arabic manuscript heritage still remained unexplored, which, first of all, was due to the sheer amount and variety of material $[5$, p. 63].

We should mention Russian researchers C.G.Zaleman, V.R. Rosen, V.F.Girgas, A. A. Romaskevich, I. Yu. Krachkovsky [6], A. B. Khalidov [7], O. B. Frolova [8], V.I.Belyaeva, M.S.Pelevin [9], as the ones who studied Oriental manuscript collections, and some of them also supplemented collections in different years. However, despite the lively interest of researchers in the manuscript collections of St. Petersburg and other oriental studies centers of Russia, only a small part of them was subjected to close analysis, and most remain unexplored [10, p. 26-31].

Various methods are used for a comprehensive study of manuscript composition. First of all, you should pay attention to the study of external features of the work - its size, degree of dilapidation, quality and condition of the binding and paper, as well as the presence or absence of filigree. All these nuances make it possible to make precise conclusions about the time of the creation of a particular manuscript. The external characteristic 
of the composition is the type of paper, handwriting, the presence or absence of a paper line (lines of vertex and ponceau), information about ink, handwriting - are also an important part of the study of a manuscript. The next stage is a deeper analysis of the text of the work, revealing its features, comparing it with similar texts. Detailed study of the text often allows the scholar not only to accurately date the manuscript, but also to establish who the copyist was, and also to whom it belonged. At the moment, researchers have a significant arsenal of modern methods of studying manuscripts, starting with infrared and ultraviolet studies of ink and paper and ending with a nuclear analysis, which allows obtaining the most complete information about the origin and features of a manuscript.

Together with the need to comprehensively study and systematize information about available Arabic manuscripts, it is necessary to emphasize the role of detailed descriptions of individual manuscripts that allow us to establish general patterns in the works of Arab authors.

Among Arabic manuscripts, Mağma' al-amtāl (Collection of Proverbs) by alMaydāni is of particular research interest. We studied three copies of the manuscript: copy B-908 from the collection of the Institute of Oriental Manuscripts of the Russian Academy of Sciences, which includes two parts; copy No. 804 from the collection of the Oriental Department of Gorky Library at St. Petersburg State University, containing only the first part of the work; and copy Lbg. 815 from the collection of the National Library of Berlin, which includes the second part of the work of al-Maydāni.

Abū al-Faḍl 'Aḥmad b. Muhammad al-Nīsbūrī al-Maydānī was born in the city of Nishapur in the Maydān district. The year of his birth was not established. Al-Maydānī died in $518 \mathrm{AH}$, which corresponds to the year 1142 according to the Christian calendar.

The medieval Muslim scholar Yāqūt al-Ḥamawī wrote about al-Maydānī, "He (alMaydānī) is an excellent scholar, grammarian, linguist. He died in 518, is buried in Maydān. The composition Al-ğāmi fí al-'amtāal (Collection of Proverbs) belongs to him, and this is a beautiful work" [11, p.511-513].

Yāqūt al-Ḥamawī also describes the following curious story: when al-Maydāni completed the work on Al-ğḡmi' fì al-'amțāl, the writer and philosopher Abū al-Qāsim al-Zamahšarī got jealous of how comprehensive and good al-Maydānīs work was. AlZamaȟšari took a pen and added the letter nūn to the name of al-Maydānī, which turned the latter's name into al-Namaydānī, which in Persian means someone who does not know anything. When al-Maydāni discovered this, he took one of the works of al- Zamaȟšari and also added the letter nün to the author's name to make it read as al-Zanahšarì. This name means in the Persian language the one who sold his wife. This story is mentioned in a number of sources, including the B-908 manuscript from the collection of the Institute of Oriental Manuscripts on page 1.

Yāqūt al-Ḥamawī wrote, referring to contemporaries who knew al-Maydānī personally, the following, "If intelligence, nobility and generosity had a face, it would be the face of al-Maydānī” [11, p. 513].

Al-Maydānī studied with outstanding scholars of his time, one of whom was the famous Koran commentator Abū al-Ḥasan al-Wāhidìi. The famous al thinker Abū al-Ḥasan al-Bayhaqī and al-Maydani’s son Sa'ìd became the students of al-Maydānī himself.

In the catalog of A. B. Khalidov said that al-Maydānī is

\footnotetext{
${ }^{1}$ Another version reads the one that has bought a wife.
} 
"a popular collection of Arabic proverbs arranged in an alphabetical order; each proverb is accompanied by a more or less understandable explanation (of individual words, grammatical constructions, the origins and uses of the proverbs). The collection has the author's foreword and consists of 28 chapters on the number of letters in the Arabic alphabet. There are also the 29th chapter, listing the days (battles) of the Arabs and the days (battles) of Islam and the 30th chapter, which contains sayings of Muhammad and prominent figures of Islam. The time of copying is the $17^{\text {th }}$ century. Sheets 01 a and $1 a$ have the owners' inscriptions. Sheet la carries a small oval stamp and an Asian Museum stamp" [12, p. 65-66].

The writing we are interested in has various names. 'Ibn Huallikān - a famous Arab writer and jurist - called the work al-Maydānī Kitäb al-amtāal (Book of Proverbs) [13, p. 6]. Yàqūt al-Hamawī referred to it as Ğāmi' al-amtâl. The most common title today is Mağma' al-'amtāl. Al-Maydānī himself refers to his work as Mağma'al-'amtāal in the introduction on sheet 6 of copy 804 and on sheet 3 of copy 908 (Fig. 1, 2).

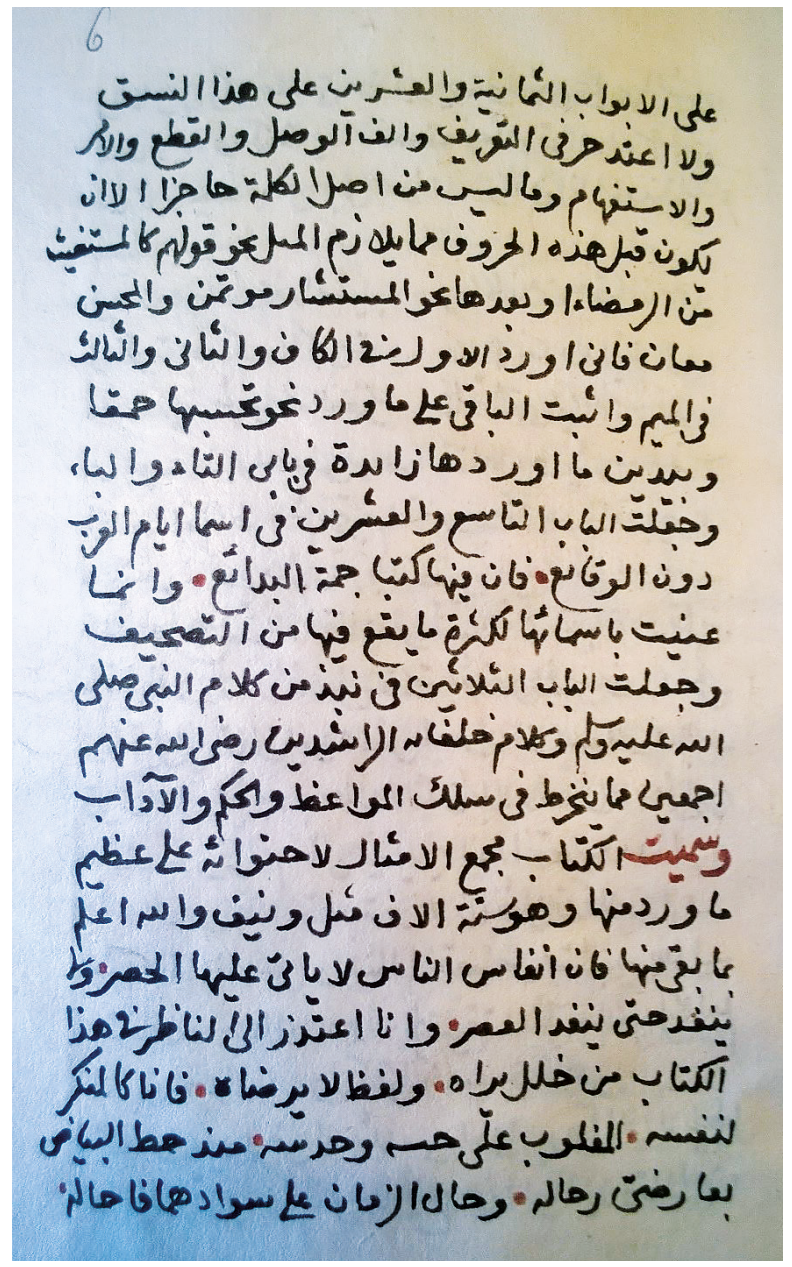

Fig. 1. Copy sheet 804 (from the Oriental Department of Gorky Library, St. Petersburg State University) 


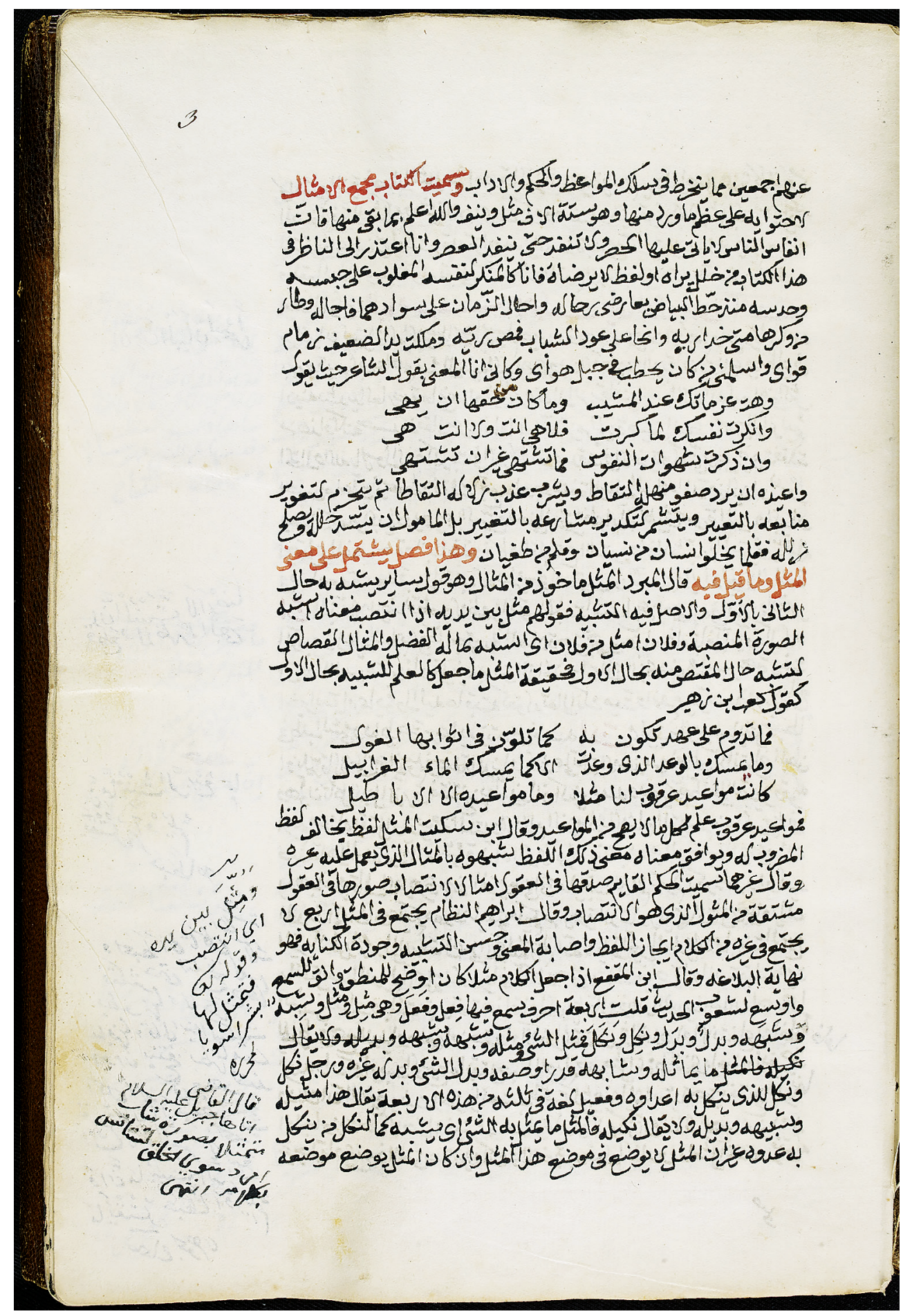

Fig. 2. Copy sheet 908 (from the Institute of Oriental Manuscripts of the Russian Academy of Sciences) 
Manuscript B-908 from the collection of the Institute of Oriental Manuscripts of the Russian Academy of Sciences is called Mağma' al-amtāl al-Maydānī. The dimensions of this copy are $25 \mathrm{~cm}$ by $16 \mathrm{~cm}$. The copy includes 286 sheets. The cover of the composition is ornamented, half-leather. In general, the book is in good condition.

The text of the piece is preceded by an inscription made on the title page of the copy

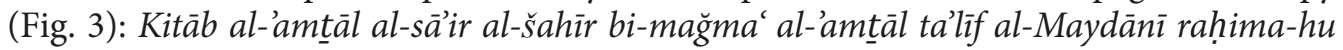
Allāh ta'alā (Translation: The book of well-known proverbs in the collection of proverbs under the authorship of al-Maydānī, may Allah be merciful to him!).

On the left-hand side of the title sheet there is a text written without dots in letters and without any voices: Al-Husayn Yüsuf min al-ábd al-faqìr al-salähiyya al-mudarris bi-al-madrasa kull man ğalaba 'ilay-hā (unintelligible) 'afā Allāh 'an-hu wa gafara la-hu (Translation: Al-Husayn Yūsuf from a poor slave, school teacher. Aleppo. God forgive him!).

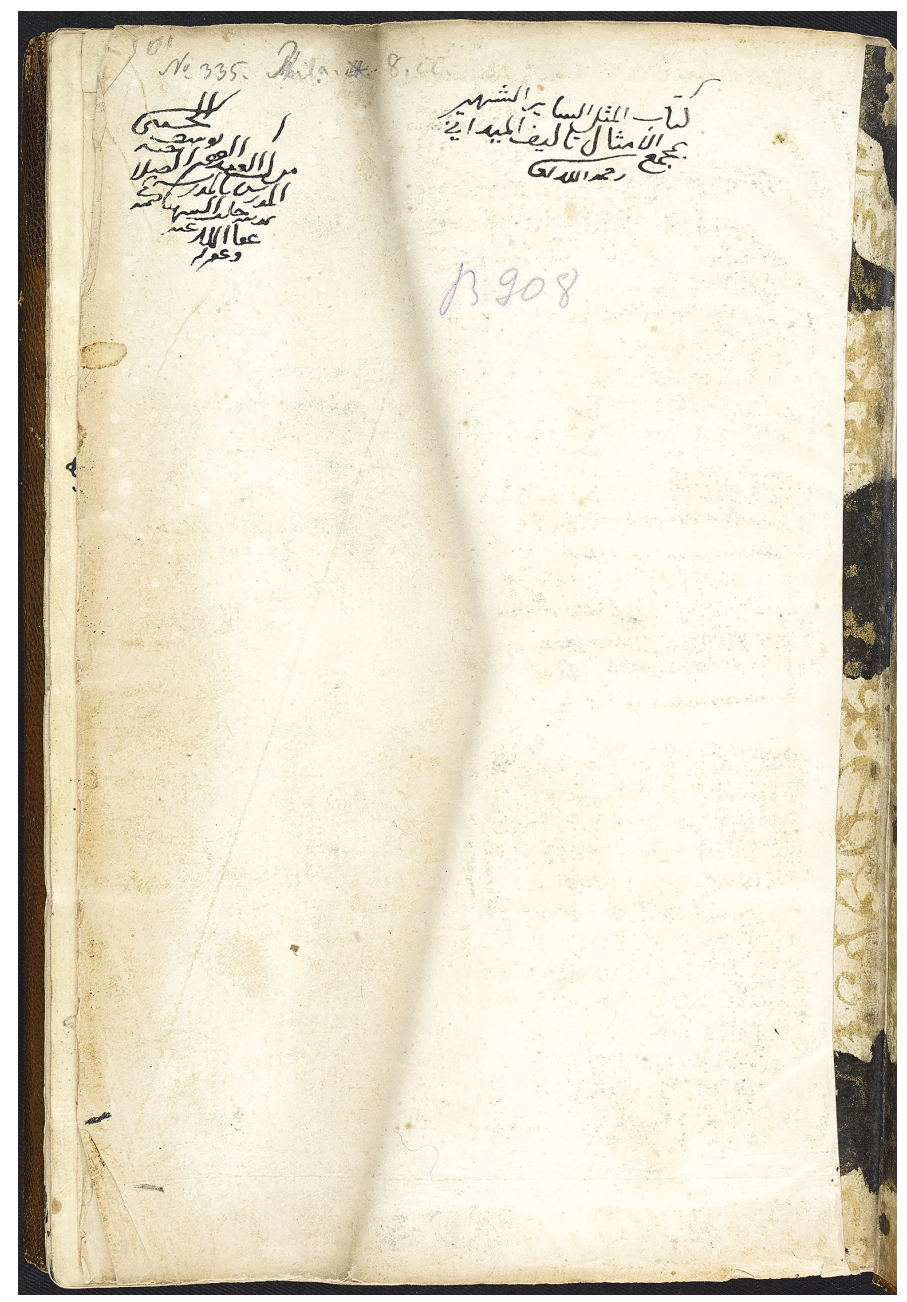

Fig. 3. Title sheet of copy B-908 (from the Institute of Oriental Manuscripts of the Russian Academy of Sciences) 


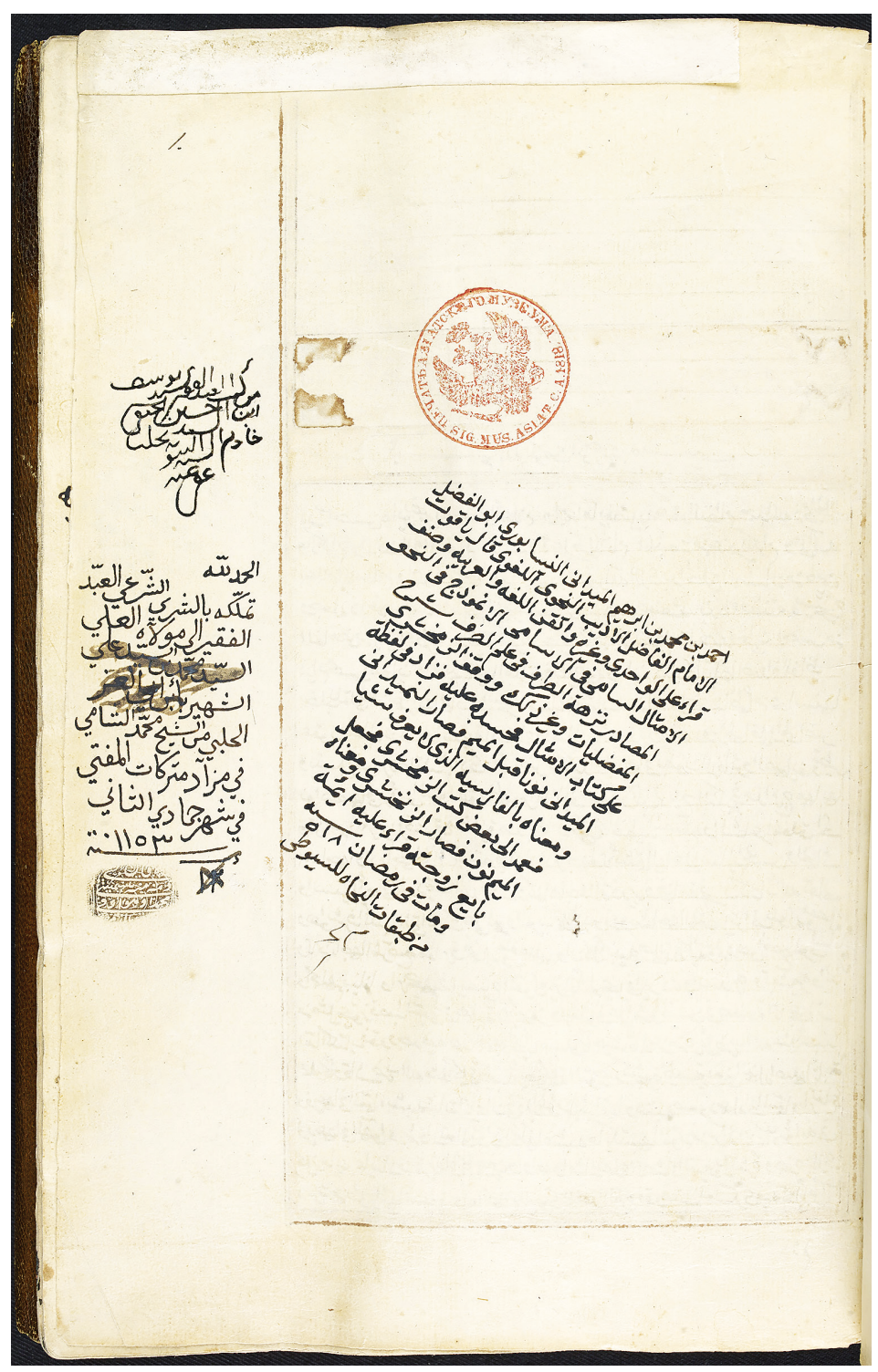

Fig. 4. The first copy of the B-908 copy (from the Institute of Oriental Manuscripts of the Russian Academy of Sciences)

On the first sheet of this copy to the left of the Asian Museum stamp ${ }^{2}$ there is an inscription containing information about the owner of the book. In this phrase, there are also no points for letters and vowels (Fig. 4):

min kutub al-'abd al-faqìr al-sayyid Yūsuf b. al-sayyid Husayn al-Hanafì hāàim al-sunna al-nabawiyya bi-Halab. 'Ufiya 'an-hu. (Translation: From the (collection) books of the poor slave of Mr. Yüsuf, the son of Mr. Husayn al-Hanafī, the servant of the Sunnah of the Prophet in Aleppo. God forgive him!).

${ }^{2}$ Sig. Mus. Asiat. C. A. 1818. 
Then follows the inscription: al-hamd li-Allāh tamallaka-hu bi-al-šarì al-šar'ì al-'áad al-faqì 'ilà maylā-hu al-áli. The next fragment of the text is crossed out, but readable; this traditionally happened when the book changed owner and the name of the previous owner of the manuscript was struck out or completely erased:

al-sayyid Muhammad b. al-sayyid 'Alī al-šahìr bi-'Abū al-'Izz. The text follows without strikethrough: al-Halabì min al-šayh Muhammad al-Šàmī fì mazād matrakāt al-muftì fì šahr ğumādì al-țānì sana 1153 (Translation: Thank God, it became the property of a poor slave with the legitimate acquisition of Mr. Muhammad, the son of Mr. Alī, known as 'Abū al-'Izz (further without strikethrough) al-Halabī from Sheikh Muhammada alŠāmī (purchased) at the auction of the mufti's things in the month of Jumad al-sani, in 1153).

Below on this sheet there is a stamp on which it is possible to decipher only some words: qāla, rabbī, Muhammad.

On the same sheet, the information about al-Maydānī, mentioned by Yāqūt alHamawī, is repeated.

B-908 European copy paper with filigree; yellowed. The text of the copy is written in a clear, intelligeable handwriting, which is a combination of nash and ruq'a handwriting. The main text is written in black ink, but individual words and phrases are highlighted in red ink. On the back of the first sheet there are traditional 'unwān and basmala. The text of the piece is limited to the back of the first sheet; on the second sheet it is inscribed in a gilded frame. On the margins of some pages there are comments made in different handwritings in black, rarely red ink. Throughout the text of the work al-Maydāni there are custodes. Each sheet has 33 lines (Fig. 5). It is written in the collage on the last sheet number 286 (Fig. 6):

'intahā kitāb al-amțāl al-ǵazìr al-'ašbāh wa-al-amtāal wa-al-hamd li-Allāh al-wāhid alkarìm al-muta'āl wa-sallā Allāh 'alā sayyidi-nā Muhammad wa-'ahli-hi wa-'azwāği-hi wa-duryati-hi wa-ahl bayti-hi wa-așhāabi-hi tasallam ${ }^{3}$ taslìman 'ilā yawm al-dīn 'amìn amin amin mìm mìm mìm

(Translation: The proverb book is completed, which is full of comparisons and proverbs, thank God the One, the Bountiful, the Most High. God blessed our master Muhammad, his family, his wives, his descendants, his relatives and associates, and he blessed him until the day of judgment. Amen, Amen, Amen, the End.)

The scribe's name, which is sometimes present even in the collage, is not indicated in this case.

The second copy we studied, No. 804 of al-Maydānī, belongs to the collection of the manuscript collection of the Oriental Department of the Gorky Library of St. Petersburg State University and is called Al-ğuz' al-'awwal min mağma'al-'amtāl al-Maydānī (The first part of Proverbs al-Maydānī).

The size of this copy is $23 \mathrm{~cm}$ by $17 \mathrm{~cm}$. In total, there are 179 sheets in the composition. Cover copy cardboard. The paper is European, of varying density with filigree.

\footnotetext{
3 This was probably a mistake in the use of the verb form tasallam instead sallam.

4 The letter mim was repeated three times in the manuscript and signifies the end of the piece.
} 


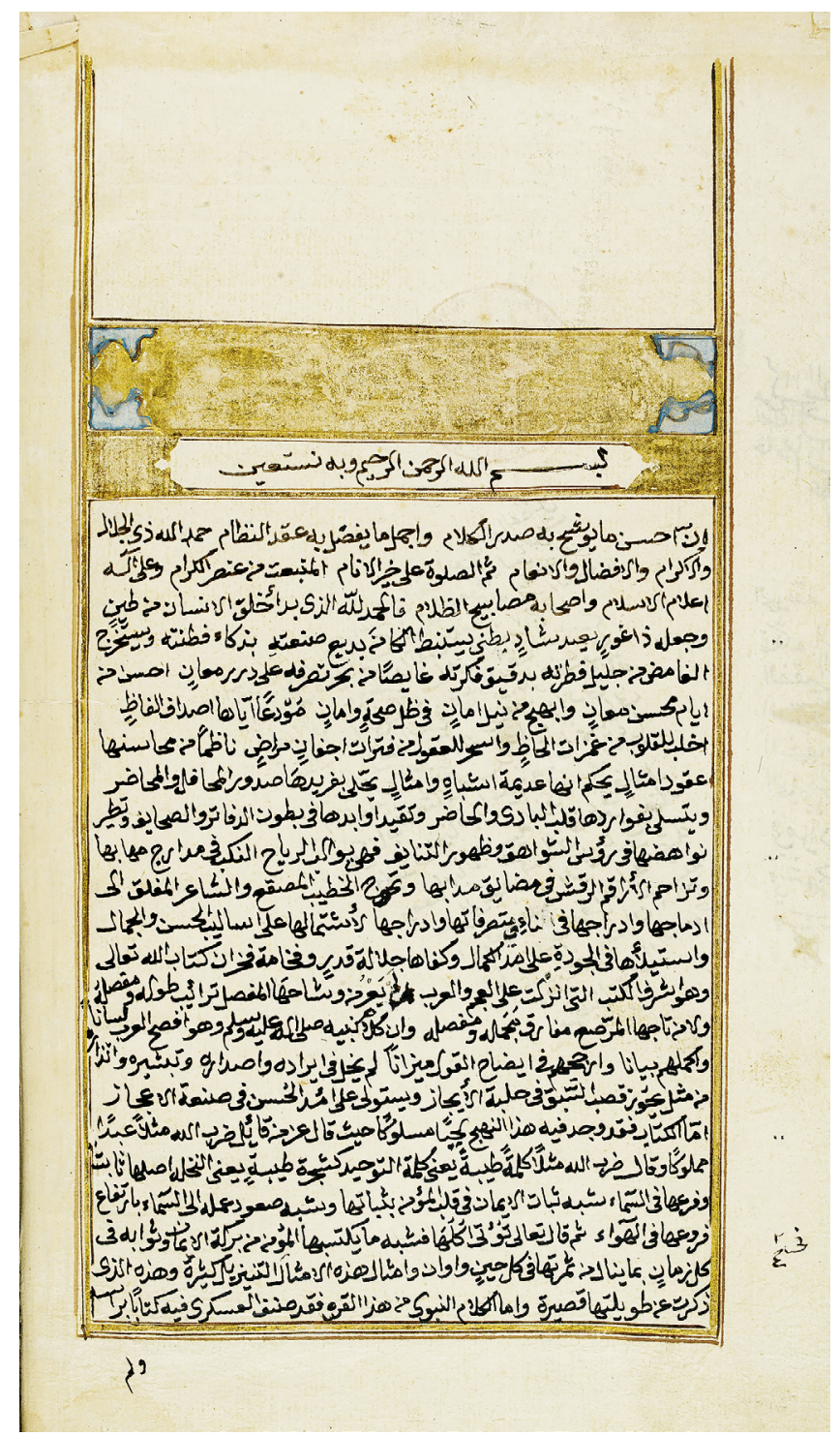

Fig. 5. The back of the first sheet of copy B-908 (from the Institute of Oriental Manuscripts of the Russian Academy of Sciences)

The text of the composition as well as in the copy of B-908 is written in two handwritings - nash and ruq'a, throughout the composition there are custodes. For the main text, the scribe used black ink, however the table of contents, the first word of each proverb and the commas are highlighted in red ink (Fig. 7).

It is interesting to note that the copy of the work was probably written by the famous Egyptian philologist aț-T Tantāinī, ${ }^{5}$ which is mentioned in I. Yu. Krachkovsky [14, p. 109], as well as from V.I. Belyaeva and P. G. Bulgakov [15, p. 25].

5 Aṭ-Ṭanțāwī taught at St Petersburg between 1840 and 1861. 


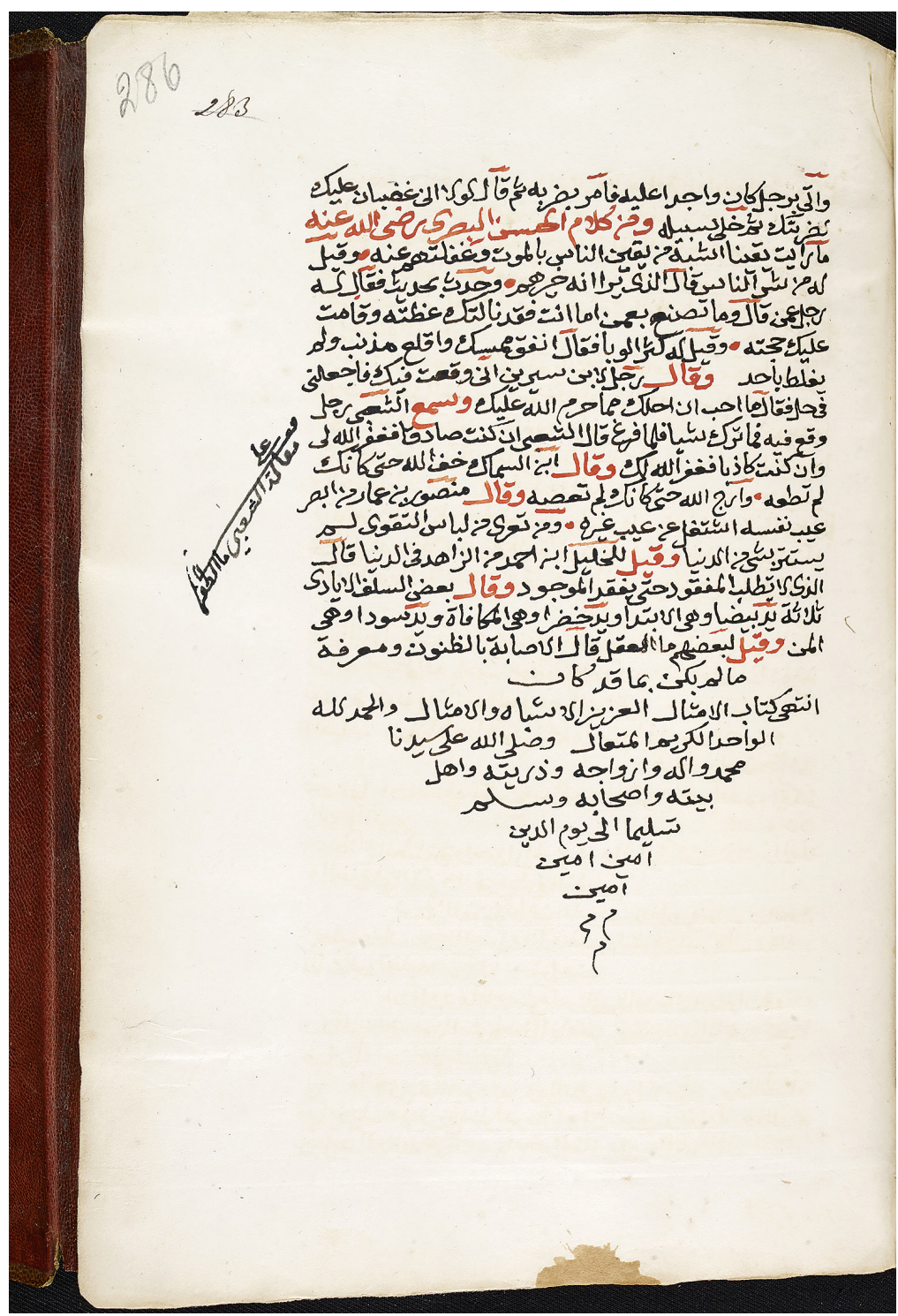

Fig. 6. The last sheet of copy B-908 (from the Institute of Oriental Manuscripts of the Russian Academy of Sciences)

Copy of Lbg. 815, belonging to the National Library of Berlin, also includes only one part of the composition of al-Maydānī, but unlike the copy of 804, this is the second part of the work. The copy is called Al-ğuz' al-țānì min mağma' al-'amtāl al-Maydānī (The second part of the collection of proverbs al-Maydānī).

The size of the Lbg list. 815 is $22.5 \mathrm{~cm}$ by $15.5 \mathrm{~cm}$. The cover of the composition is leather, brown. The condition of the copy is satisfactory - in some places the paper was damaged by insects and subsequently restored. The paper without filigree, east, thick enough, yellowed. Some pages are strongly stuck together. 


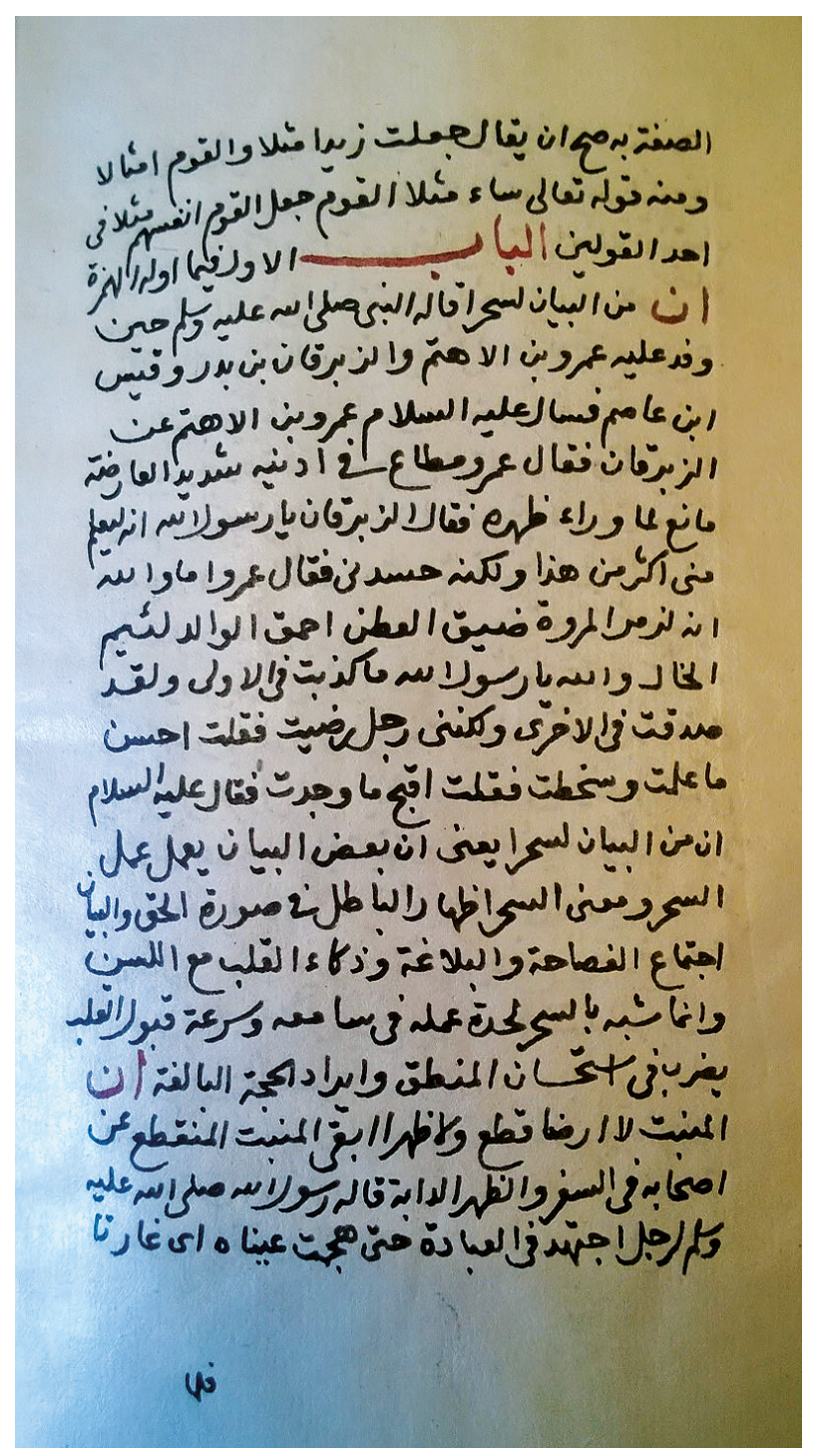

Fig. 7. Fragment of copy 804 (from the Oriental Department of Gorky Library, St. Petersburg State University)

On the title page of the copy of Lbg. 815, there are numerous inscriptions in addition to the name of the composition and the stamp of the library, ${ }^{6}$ the letters in some of them are completely devoid of points (Fig. 8):

I. al-hamd li-Allāh (inaudible) fi nawba (inaudible) Hamad b. Muḥammad (part of the page is cut off) al-Mawsawì al-Šäfì lataf Allāh bi-hi

(Translation: Glory to God (inaudible) in possession of Ḥamad bin Muhammad (part of the page is cut off) al-Mawsawī al-Šăfi'i, may God be merciful to him)

${ }^{6}$ Ex. Biblioth. Regia Berolinensi. 
II. fuhrisat fì kutub al-'abd al-faqìr 'ilā raḥmat Allāh hallaṣ-hu Allāh min al-tabàat

tumma fì nawbat al-mawlawiya al-șāğiya walad šayḩ al-šuyūh

(Translation: This manuscript was included in the copy of books of a poor slave, his heavenly kingdom, May God save him from the consequences (sins), then in possession of the dervishes (?) Of the sheik's son)

III. al-ḥamd li-Allāh ta'ālà waḥda-hu

hā $\underline{d} \bar{a}$ wa-mā qabla-hu mimmā șār fì nawbat al-faqìr 'ilay-hi subhāna-hu wa-ta'àlà 'Abd al-Karìm b. Muhammad b. Muḥammad b. Muhammad b. al-Šayh Hamza al-Hašbanī alDima!̣ qì gafara-hu Allāh fì ră̆ab min sanat 1113 bi-al-širā al-šar'ī

(Translation: Glory be to God the Supreme One. This is both what was before and what the poor took over. 'Abd al-Karīm b. Muhammad b. Muhammad b. Muhammad b. alŠayh Hamza al-Hašbanī al-Dimašqī, God forgive him, in (month) rajab in 1113 by legal purchase)

IV. al-ḥamd li-waliya-hi tumma sāqa-hu sāiq al-taqdìr min qabla-hu ilā nawbat al-'abd al-faqìr Răgab 'ibn 'Abd al-Karìm b. Muhammad b. Hamza al-Hasanī

'ahsan Allāh 'awāqiba-hu wa-faḍ̣il bi-al-širā al-šar'ì fì sanat 1118

(Translation: Glory to his viceroy ${ }^{7}$

Then fate transferred (this book) to the possession of the poor slave Rağab 'ibn 'Abd alKarīm b. Muhammad b. Hamza al-Hasanī, may God make his affairs auspicious. It was acquired legally in 1118)

V. katab (inaudible) al-dūhād al-'izzī bi-ta’rīh răgab al-fard sana (illegible) Allāh almaḥmūd 'alà kull ḥāl wa-na'ū $\underline{d}$ bi-hi min ḥāl 'ahl al-nāra

wa-katab (illegible) lațaf Allāh bi-hi

faqìr 'ilā mawlā-hu yas'al 'afwa-hu wa-yarğ̄u 'ațāyā-hu (illegible)

yaǵfur zallāt wa-yastur 'aura wa-yudhib' 'an-hu

wa-yūlī-hi min-hu kull šay'yarūmu-hu wa-yă̆gala-hu 'abdan la-hu

'abda-ka wa-ta'attaf 'alay-hi wa-'urzuqh min faḍli-ka yā rabb al-älimīn (illegible)

wa-șalli 'awwalan wa-ähiran wa-bāținan wa-ẓāhiran 'alā Muhammad wa-äli-hi wașahbihim

(Translation: I wrote al-Izzī in the month of rajab ... a year ... in the name of God.) God is glorious and he will save from bad people.

And wrote (illegible) let God be merciful to him. The poor (slave) asks his master for his forgiveness and his retribution (illegible). He asks for forgiveness of mistakes, (requests) to hide his shortcomings and to save him (from all bad things), to grant him that he (God) wishes to make him his slave. (He) is your slave, have mercy on him and grant him out of your blessings, Most High. Constantly raise the prayer explicitly and disgorged Muhammad, his family and their companions)

\footnotetext{
7 Prophet Muhammad, the governor of God on earth.
}

8 God is meant. 


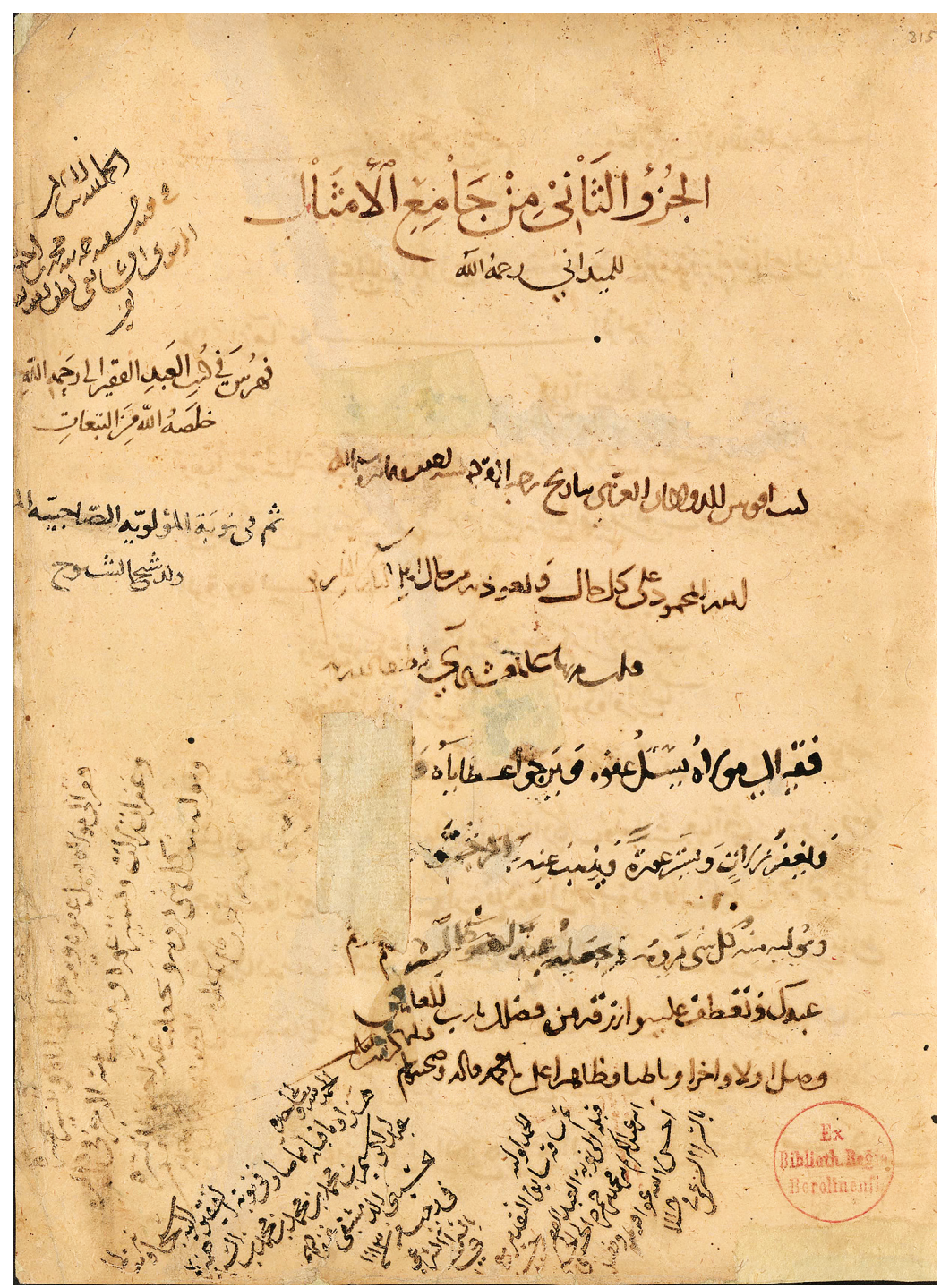

Fig. 8. Title sheet of copy Lbg. 815 (from the National Library of Berlin)

It should be noted that on the title page there is also an inscription duplicating a fragment of the text above, but written in a bad hand:

faqīr 'ilā mawlā-hu yas'al 'afwa-hu wa-yarğ̄̄ 'ațāyā-hu (illegible)

yaǵfur zallāt wa-yastur 'aura wa-yudhib'an-hu

wa-yūlīh min-hu kull šay' yarūmu-hu wa-yă̆gala-hu 'abdan la-hu

The entire text of the work is written in a clear and intelligible handwriting nash. In the text there are custodes, there are rare comments on the fields. A distinctive feature of this copy is that the text is fully voiced (Fig.9). 


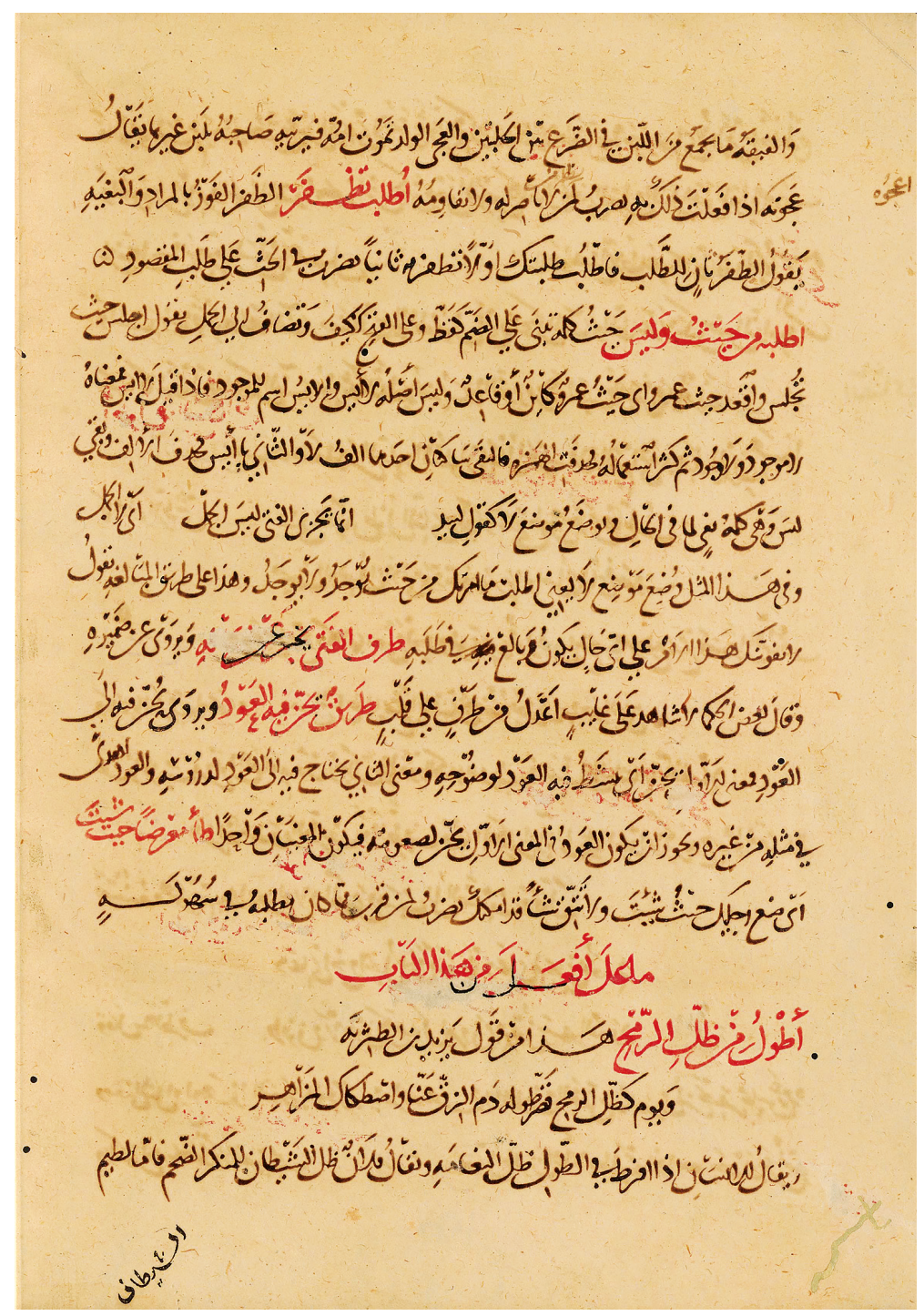

Fig. 9. A fragment of the copy Lbg. 815 (from the National Library of Berlin)

It should be noted that the National Library of Berlin also contains a complete list of works of al-Maydānī - Df. 62. Information about him is in the catalog of Arabic manuscripts of the library [16, p. 594], but it is impossible to see the copy itself at the moment, as it is in a dilapidated state and is not available for examination.

Structurally, the composition al-Maydāni includes 30 chapters, the names of which are arranged in alphabetical order. Moreover, the $28^{\text {th }}$ chapter includes proverbs beginning with the letter $y \bar{a}$, the $29^{\text {th }}$ chapter unites the names of festive and memorable days in history, and the $30^{\text {th }}$ chapter is entirely devoted to the statements of the Prophet and righteous caliphs (Fig. 10). 


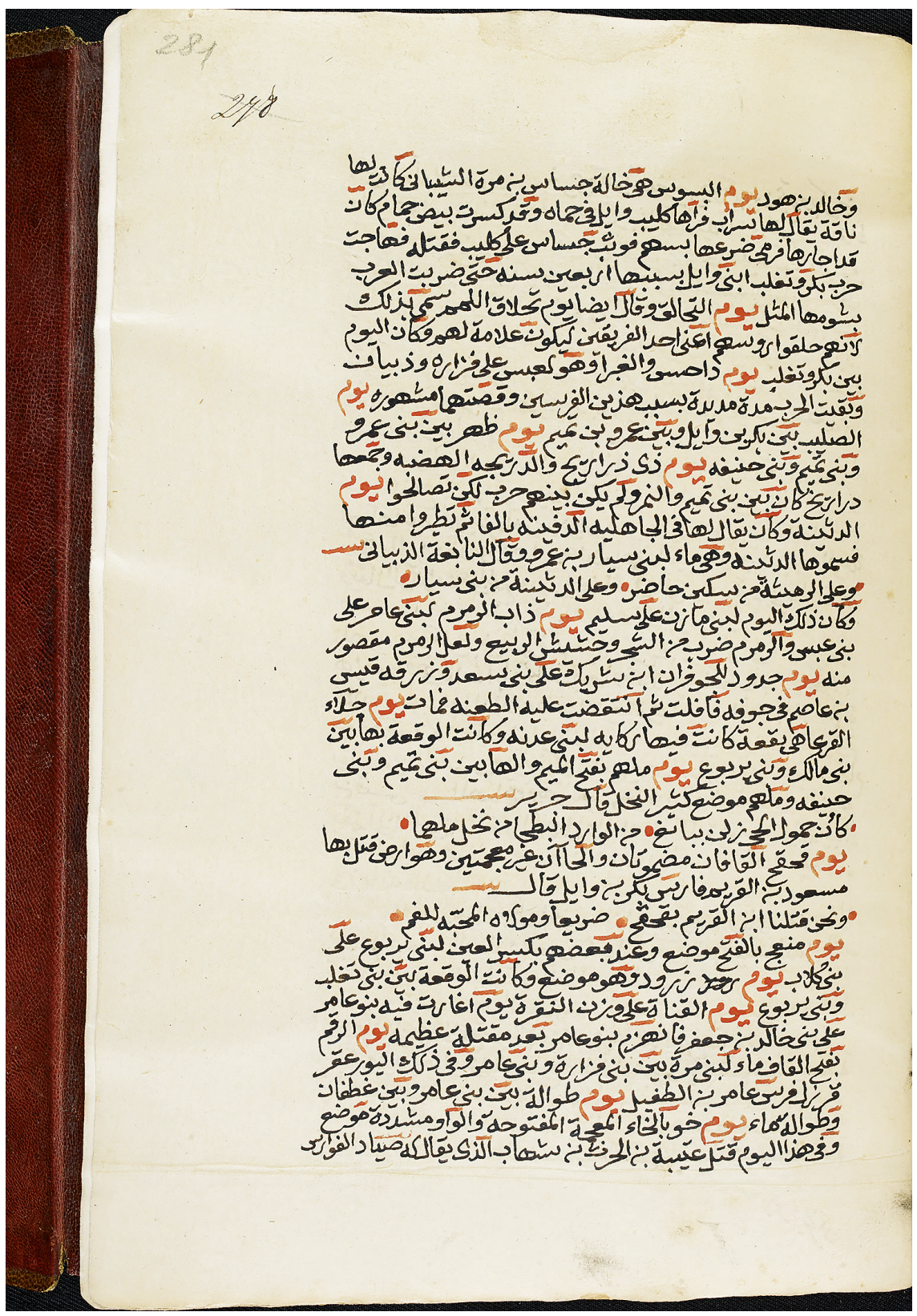

Fig. 10. A fragment of copy B-908 (from the Institute of Oriental Manuscripts of the Russian Academy of Sciences)

Each chapter of the work begins with ordinary proverbs, followed by proverbs grouped by the use of the 'af'al in them (Fig. 11).

After that, the proverbs composed by the speakers of the Arabic language are not Arabs by origin - this part is called 'amtâl al-muwalladīn (Fig. 12). 


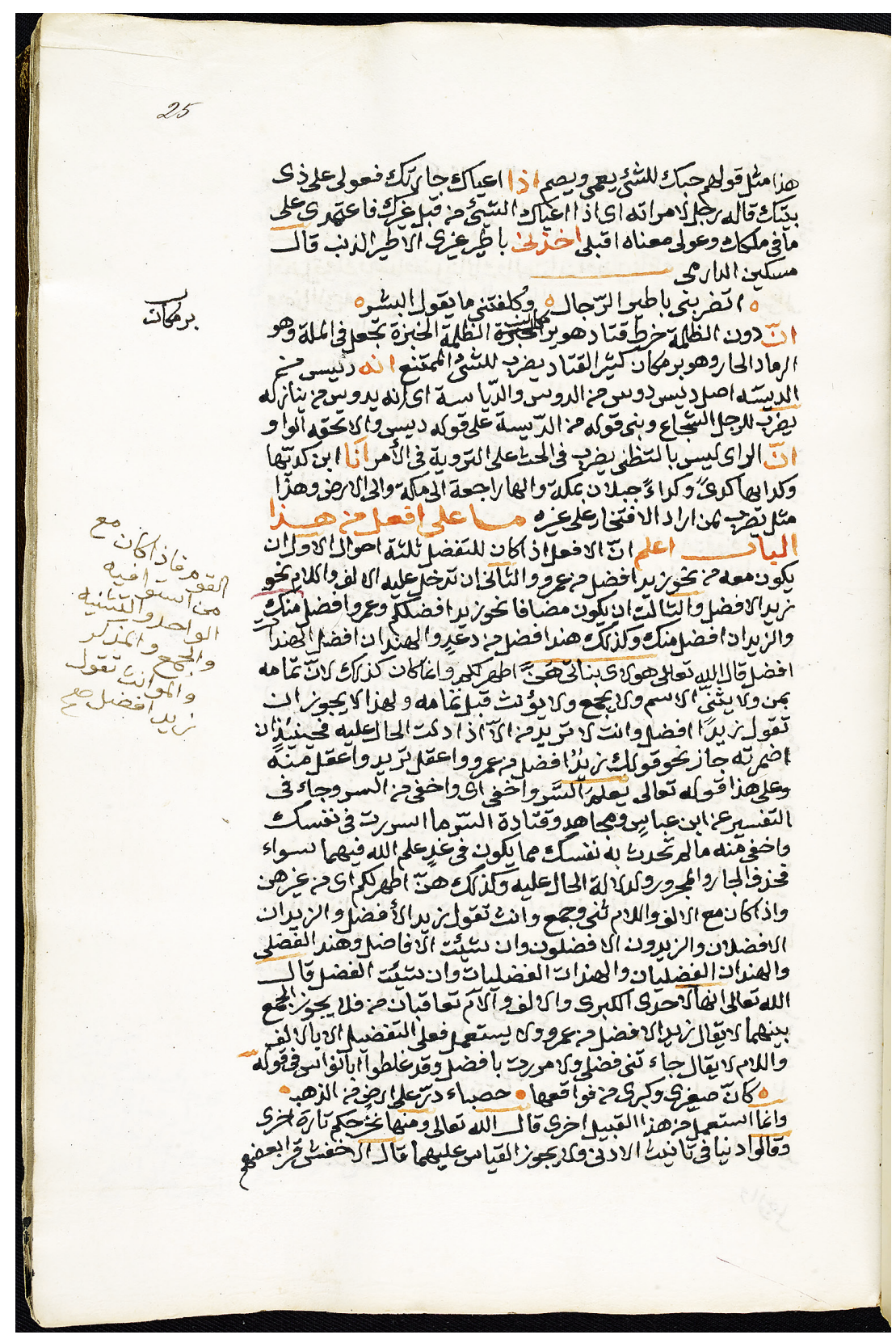

Fig. 11. The fragment of copy B-908 (from the Institute of Oriental Manuscripts of the Russian Academy of Sciences)

The subjects of the proverbs included in this literary work are diverse: the animal world, the planets, as well as citations from the well-known bait, which later became proverbs. It is interesting to note that a large number of such baits belong to the poet alMutanabbī. Some proverbs are grouped according to the use in them of the terms of kinship (mother, father, brother, etc.), others have a prehistory of appearance. 


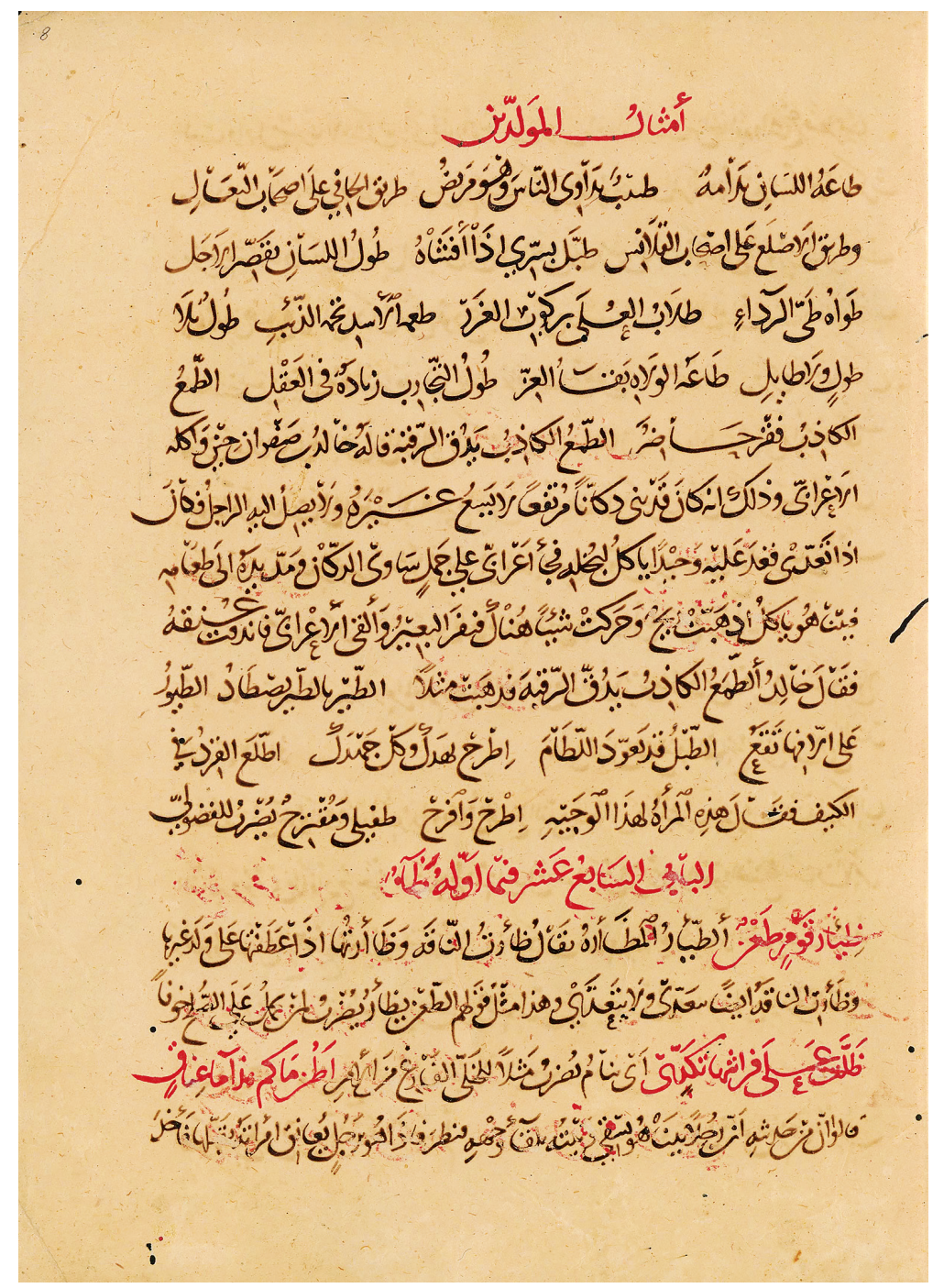

Fig. 12. A fragment of copy Lbg. 815 (from the National Library of Berlin)

Let's consider some examples in more detail, dividing them into the appropriate groups.

1. Proverbs using the terms of kinship.

- 'inn al-hamāt 'awla'at bi-al-kanna wa-'awla'at kannatu-ha bi-al-zanna

They talk about constant hostility between a mother-in-law and a daughter-in-law.

- 'ilā 'ummi-hi yalhaf li-al-lahfan

They say that when a person turns to his relatives for help.

- 'umm farašat fa'anāmat

They speak of a good attitude to a member of a loved one.

- 'ahāa-ka 'ahāa-ka 'inna man lā 'ah̆ la-hu kasā' 'ilā al-hayğa bi-gayr silāh

They say when you need to support a loved one. 
2. Proverbs using anatomical terminology.

- 'idāa ğă al-hịn ḥārat al-'ayn 'id a à ğà al-qadar gašiza al-bașar

They say, when everything is already decided and nothing can be changed.

- 'inna-hu la-šadìd ğafn al-'ayn

They talk about a person who can stay awake for a long time.

- 'anf fì al-samä' wa-'ist fì al-mä

They speak of a stupid and arrogant person.

3. Proverbs about women.

- 'inna al-nisā' šaqäq al-'aqwām

They say to emphasize the equality of women and men.

4. Proverbs using the image of animals.

- 'idea 'arād Allāh halak al-namla 'anbat la-hu ğanāḥayn

If God wants an ant to die, he will give him wings.

- 'idā dakarta al-di'b fa'a'idd la-hu al-'așā

If you remember the wolf, prepare a stick.

- 'idà lam yanfáa-ka al-bāzì fantif rī̌sa-hu

If you do not need a falcon, pluck it.

5. Proverbs using the grammatical form 'af'al.

- 'abșar min zarqä' al-yamāma

They talk about a person with excellent eyesight.

6. Poetic lines that have become proverbs.

- 'id̄a 'akramta al-karim malakta-hu wa-'inn 'anta 'akramta li-al-la'ìm tamarradā

Doing good to a noble (man), you multiply his nobility, if you do good to the low (man), he becomes even lower.

The fact that Mağma' al-amtāl continues to be reprinted can only indicate that the interest in the work of al-Maydāni is still unabated. Most proverbs, which the author included in his work several centuries ago, are used to this day.

The study of the surviving copies of this manuscript makes it possible to get the most complete understanding of one of the most major works of the Arab thinker and scholar al-Maydānī, and also enables researchers to look at the whole cultural and historical layer through the prism of proverbs used in living speech.

The medieval culture of the Muslim world cannot be fully understood without a comprehensive study of the entire Arabic manuscript tradition and a thorough examination of Arabic manuscripts. Attention to Arabic manuscripts derives from their immense historical and cultural significance as an invaluable source of information about the most diverse

${ }^{9}$ According to legend Zarqä al-yamāma is the name of the woman whose sharp eyes allowed her to see a person who was at a distance of a three-days' walk from her. 
fields of science, art, history of political and religious thought in the Middle East and in neighboring regions.

\section{References}

1. Khalidov A. B., Mikhailova I. B. Bibliografiia arabskih rukopisey [Bibliography of Arabic manuscripts]. Moscow, Nauka Publ., 1982. 392 p. (In Russian)

2. Brockelmann C. Geschichte der Arabischen Litteratur, B. I-II. Weimar, Berlin, 1898-1902. 714 p.

3. Brockelmann C. Geschichte der Arabischen Litteratur, SB II. Leiden, Brill, 1938. 780 p.

4. Sezgin F. Geschichte des arabischen Schrifttums (GAS). Leiden, Brill, 1967. 406 p.

5. Khalidov A.B. Arabskie rukopisi $v$ SSSR $i$ ih izuchenie [Arabic manuscripts in the USSR and their study]. Archaeographic Yearbook for 1977. Moscow, 1978, pp.62-78. (In Russian)

6. Krachkovsky I. Yu. Izbrannie sochineniia v shesti tomakh [Selected works in six volumes]. Volume Five. Moscow, Leningrad, Publishing House of the Academy of Sciences, 1955-1960. 526 p. (In Russian)

7. Khalidov A. B. Arabskie rukopisi Instituta vostokovedeniia: kratkii katalog [Arabic manuscripts of the Institute of Oriental Studies: a brief catalog]. Moscow, Nauka Publ., 1986. 237 p. (In Russian)

8. Frolova O. B. Arabskie rukopisi vostochnogo otdela nauchnoi biblioteki SPbGU. Kratkii katalog [Arabic manuscripts of the eastern section of the St. Petersburg State University's Scientific Library: A Brief Catalog]. St. Petersburg, Center "Petersburg Oriental Studies", 1996. 268 p. (In Russian)

9. Pelevin M.S. Rukopisnaia i ksilograficheskaia kniga Vostoka: ocherki kodikologii [Handwritten and xylographic book of the Orient: essays on codicology]. St. Petersburg, Svoe Publishing House, 2015. 256 p. (In Russian)

10. Jamil (Hana) Y.Yu., Azarkina M.A. Rukoposi, posviashennye arabskomu glagolu [Manuscripts devoted to the Arabic verb]. Vestnik of Saint Petersburg University. Series 13 (2). Oriental Studies, African Studies. 2011, pp.26-31. (In Russian)

11. Yāqūt al-Ḥamawì. Mağma' al-'udabä' [Writers' collection]. 1993. 3560 p. (in Arabic)

12. Khalidov A. B. Katalog arabskikh rukopisei Instituta narodov Asii [Catalog of Arabic Manuscripts of the Institute of the Peoples of Asia]. Issue 1. Moscow, Publishing House of the Institute of Oriental Literature, 1960. 136 p. (In Russian)

13. 'Ibn Hallikān. Wafiyāt al-'áyān [Famous peoples' dates of death]. Vol.3. Beirut, 1972. 440 p. (in Arabic)

14. Krachkovsky I. Yu. Sheikh Tantawi. Materialy dlia biografii Tantawi v biblioteke Leningradskogo gosudarstvennogo universiteta [Sheikh Tantavi. Materials for the biography of Tantavi in the library of the Leningrad State University]. Leningrad, 1929, pp. 94-117. (In Russian)

15. Belyaev V.I., Bulgakov P.G. Arabskie rukopisi sobraniia Leningradskogo gosudarstvennogo universiteta [Arabic manuscripts of the meeting of the Leningrad State University. In memory of Academician I. Yu. Krachkovsky]. Leningrad, Leningrad University Press, 1958, pp. 21-35. (In Russian)

16. Ahlwardt, W. Die Handschriften-Verzeichnisse der koniglichen Bibliothek zu Berlin, Vol.7. Berlin, Asher \& Co, 1894. 822 p.

Received: 20.10 .2017

Accepted: 27.02.2018

Author's information:

Yafia Y.J. Hana - PhD in Philology; yhana@mail.ru

Enesh K. Akhmatshina - PhD in Political Science; enesh.bayramova@gmail.com, e.akhmatshina@spbu.ru

Amaliia A. Mokrushina - PhD in Philology; kodzik@inbox.ru 


\title{
Три списка рукописи al-Maydānī «Сборник пословиц» из Института восточных рукописей Российской академии наук, собрания восточного отдела Библиотеки им. М. Горького Санкт-Петербургского государственного университета и коллекции Национальной библиотеки Берлина
}

\author{
Я. Ю. Д. Хана, Э. К. Ахматиина, А. А. Мокрушина \\ Санкт-Петербургский государственный университет, \\ Российская Федерация, 199034, Санкт-Петербург, Университетская наб., 7-9
}

Для цитирования: Hana Y.Y.J., Mokrushina A.A., Akhmatshina E. K. Three manuscript copies of the Collection of Proverbs by al-Maydāni from the Institute of Oriental Manuscripts of the Russian Academy of Sciences, the Oriental Department of Gorky Library, St. Petersburg State University, and the National Library of Berlin // Вестник Санкт-Петербургского университета. Востоковедение и африканистика. 2018. Т. 10. Вып. 2. С. 210-229. https://doi.org/10.21638/11701/spbu13.2018.206

В последние десятилетия одним из приоритетных направлений изучения рукописной книги является кодикология. Статья посвящена анализу трех списков рукописи «Сборник пословиц» известного мусульманского ученого-лингвиста al-Maydānī. Два списка хранятся в рукописных коллекциях Санкт-Петербурга (Институт восточных рукописей РАН и восточного отдела Библиотеки им. М.Горького СПбГУ), третий принадлежит коллекции Национальной библиотеки Берлина. Сочинение al-Maydānī представляет собой сборник арабских пословиц, расположенных в алфавитном порядке. Каждая пословица сопровождается комментарием, касающимся отдельных слов, грамматических конструкций, а также происхождения и употребления. Сборник снабжен предисловием автора и включает двадцать восемь глав по числу букв арабского алфавита. В двух дополнительных главах перечислены дни битв арабов, собраны изречения Мухаммада и выдающихся деятелей ислама. Изучение сохранившихся списков рукописи позволяет составить наиболее полное впечатление об одном из самых крупных и значимых сочинений арабского мыслителя и ученого al-Maydānī, а также дает возможность исследователям взглянуть на целый культурноисторический пласт сквозь призму употребляемых в живой речи пословиц. Интерес к произведению al-Maydānī сохраняется и сегодня, а его сочинение Mă̆ma' al-àmtāl продолжает переиздаваться. Большинство пословиц, которые автор включил в свое произведение несколько веков назад, широко используются по сей день. Без целостного охвата всей арабской рукописной традиции и многопланового рассмотрения арабских манускриптов не могут быть в полной мере поняты существенные аспекты средневековой культуры мусульманского мира. Таким образом, внимание к арабской рукописной книге, которая является бесценным источником сведений о самых разнообразных областях науки, искусства, истории политической и религиозной мысли на Ближнем Востоке и в сопредельных регионах, объясняется ее огромным историко-культурным значением.

Ключевые слова: кодикология, арабская рукопись, списки рукописи, арабский язык, пословицы, фольклор.

Контактная информация:

Хана Яфиа Юсиф Джамиль - канд. филол. наук; yhana@mail.ru

Ахматшина Энеш Курбансейидовна - канд. полит. наук; enesh.bayramova@gmail.com, e.akhmatshina@spbu.ru

Мокрушина Амалия Анатольевна — канд. филол. наук; kodzik@inbox.ru 